\title{
TOURISM SECTOR IN BOSNIA AND HERZEGOVINA - STATE AND DEVELOPMENT PERSPECTIVE
}

\author{
Nusret Drešković $\mathbf{c}^{33}$ \\ Ševkija Okerić ${ }^{34}$ \\ Ranko Miric $\mathbf{c}^{35}$ \\ Amina Sivac ${ }^{36}$
}

\begin{abstract}
Basic characteristics of contemporary tourism development of Bosnia and Herzegovina and its administrative-political organization units are essentially linked to still insufficient infrastructure and legislative-institutional tourism organization. Regardless of the fact that in most development strategies of all administrative and political-organizational units in Bosnia and Herzegovina tourism is recognized as one of the basic strategies, the development level of tourism industry towards all indicators is significantly lagging behind at the level of the entire European tourism market. According to data from the Travel and Tourism Competitiveness Report of the World Economic Forum (WEF), Bosnia and Herzegovina is only 113 out of total of 136 countries, according to tourism traffic, out of a record number of 1,235 billion. Of international tourists' arrivals, which were taken worldwide in 2016, Bosnia and Herzegovina has averaged less than $0.1 \%$. The total number of tourist arrivals was around 1.149 million in 2016, of which international arrivals accounted for about $62.6 \%$, while the remaining $37.4 \%$ were domestic arrivals. The total number of nights spent in Bosnia and Herzegovina during the year 2016 was 2,377 million. In relation to the above mentioned indicators, positive trends in the number of tourists have increased in the past 10 years with an average annual rate of about 2.5\%. These data indicate that Bosnia and Herzegovina, with the improvement of institutional and infrastructure capacities, should significantly improve the overall tourism traffic and achieve a significantly better position within the regional European market in the next ten year period. Keywords: Bosnia and Herzegovina, tourism development, World economic forum, international tourist arrivals, year-on-year growth rate
\end{abstract}

\section{INTRODUCTION}

Tourism sector in Bosnia and Herzegovina is poorly documented in terms of its size, value and economic impact. Despite that, it is considered that this sector can and should make a significant contribution to improvement of the current stress situation of the balance of payments on one side and creation of opportunities for employment on the

\footnotetext{
${ }^{33}$ Associate Professor, Department of Geography, Faculty of Science, University of Sarajevo, nusret2109@gmail.com

${ }^{34}$ Assistant Professor, Department of Geography, Faculty of Science, University of Sarajevo, okeric@serda.ba

${ }^{35}$ Associate Professor, Department of Geography, Faculty of Science, University of Sarajevo, rmiric@gmail.com

${ }^{36}$ Teaching Assistant, Department of Geography, Faculty of Science, University of Sarajevo, amina.sivac@pmf.unsa.ba
} 
other side. At the global scale, tourism's development outcomes are influenced by broad-based economic change, evolving structures of corporate governance and the unrelenting evolutionary pressures of demographics and technological change (Milne and Ateljevic, 2001). Global institutions, such as the IMF and World Bank, play a vital role in shaping the economic environment for tourism investment and development in much of the world (Mowforth and Munt, 1998). The successful tourism sector brings another benefit to the country, which is an improvement of the current "post-war country" image of Bosnia and Herzegovina at the international level. Unlike in other countries, such as Croatia, the tourism sector in Bosnia and Herzegovina is not strong enough to partially balance trade deficit and it seems that no changes are to be expected in the near future. However, there is a wide opinion that this sector has the potential for growth, and that it can be the driver of a number of related service activities, as well as links between various sectors of economy. The tourism sector has an impact on many other service sectors and manufacturing industries, such as the food industry, construction and financial services. Its success is closely related to the image of the country, its political and economic stability, and the quality of its transport infrastructure and information services. Indeed, by its very nature, in terms of connections between generating areas, destinations and travel routes or paths, tourism is perhaps a phenomenon which depends more than most not only on transport, service and trading networks, but also on social, political and environmental relationships between the consumers and producers of the tourist experience (Hall, 2014). The tourism sector depends on the citizens of any country, but also affects them. It is a sector in which cash is converted, and is so prone to opening gray areas. Sustainable development of tourist destination requests controlled growth, integration of natural, economic and socio-cultural environment, and long-term planning and strategies that integrate key stakeholders in ecotourism: visitors, tourist agencies and operators, local people, hotels and supplier of services at destination (Babić-Hodović et al. 2016). However, it is noticeable that Bosnia and Herzegovina has an undeniable natural wealth, as well as cultural, historical and religious sites that are attractive to foreign tourists. The majority of guests still come from the neighborhood countries, that is, the first round of countries that have more information about Bosnia and Herzegovina than tourists from other parts of the world. This is in itself an indicator that promotion is one of the weak points of the tourism sector and that information does not reach potential guests. There is no targeted tourism market to which tourism development is oriented, and the amount of the promotional budget is unknown. Oral recommendations and diaspora, along with occasional groups of tourists in search of adventure, continue to reach the country. Many guests come for one-day or two-day visits which are part of the larger tourist arrangements in the surrounding area (eg. from the Croatian coast to Mostar, Sarajevo or Međugorje). In accordance with the strategic decision of the Council of Ministers of Bosnia and Herzegovina to determine tourism in Bosnia and Herzegovina as one of the primary economic activities that should generate economic 
growth and employment in the coming period, all administrative-organizational units in Bosnia and Herzegovina intensified their own efforts to establish an organizational improvement of all segments of the tourism industry. The results of practical government work have so far resulted in weak and mostly partial results, thus the mentioned process of systematic improvement of the tourism industry in Bosnia and Herzegovina did not give the expected positive economic effects. These shortcomings are evident in many sub-definitions of tourism market regulation, particularly from the aspect of suppressing gray economy and increasing the share of tourism in total GDP and a significant increase in employment in this area. The obvious disparity in the size and indicators of tourism trends between the tourist regions indicated the need for different spatial organization of tourism development strategy in Bosnia and Herzegovina (Mirić et al., 2017). From what has been said so far, it can be concluded that significant improvements are needed in this sector of the economy, but in the medium to long term, it can make a significant contribution to the employment of the population and the promotion of other products from Bosnia and Herzegovina. The basic indicators for this sector are given in the paper, but data reliability is to a certain point questionable because the statistical system in its current form does not provide comprehensive and accurate data in the very complex structure of this sector. Accordingly, the information given in paper corresponds only to the data of reported revenue. It is believed that the actual income is higher.

\section{INSTITUTIONAL FRAMEWORK, LEGISLATION AND LAWS}

The institutional structure of Bosnia and Herzegovina, often referred to as one of the main obstacles to overall economic development, is also an obstacle to tourism development. However, slow progress in the development of tourism in Bosnia and Herzegovina cannot be justified only by a complex institutional structure. Local authorities and local communities, as well as private business entities and tourism organizations, may be more active in enabling tourism development within its competence and at the micro level. Indeed, the regulatory, institutional and legislation framework is complex, leaving little space for the efficiency and coordination of tourism activity in Bosnia and Herzegovina. Such a stratification of regulatory infrastructure is shown in the Fig 1.

When it comes to the institutional framework for supporting the promotion and strengthening of the tourism sector in Bosnia and Herzegovina, there is no institution at the national level, but at the entity levels there are Tourist Board of the entity of Federation of Bosnia and Herzegovina and a Tourist Organization of the entity of Republic of Srpska. The primary role of these institutions is the promotion and strengthening of the tourism sector. However, the Tourist Association of the Federation of Bosnia and Herzegovina is further organized in 10 cantonal tourist communities, while the Tourist Organization of entity of Republic of Srpska is further organized in 32 
municipal tourist organizations, whose main task is also the promotion of tourist facilities. The Foreign Trade Chamber of Bosnia and Herzegovina, whose primary task is promotion, the strengthening of the tourism sector and the representation of the interests of legal entities in the Tourism and Hospitality Affiliation, is further organized in the chambers of commerce of both Entities, which are in charge of promotion, sector strengthening and representation of legal entities in tourism and hospitality associations. There are also two important associations at the state level: the Association of Tourist Agencies of Bosnia and Herzegovina and the Hotel and Restaurant Association of Bosnia and Herzegovina, which primarily deal with the representation of their members' interests.

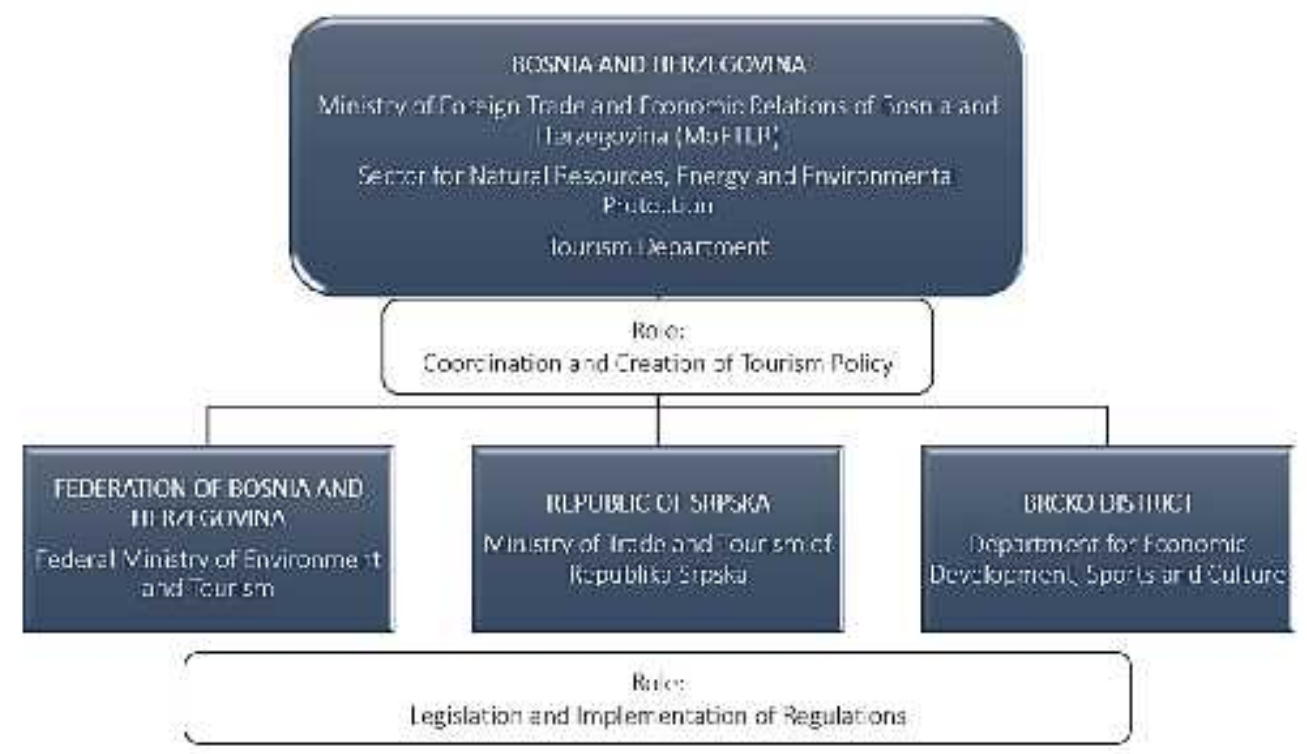

Fig. 1: Organization of Tourist Sector in Bosnia and Herzegovina - Regulatory frame

There is no Law on Tourism at the state level in Bosnia and Herzegovina. In accordance to the Dayton Peace Agreement, entities and Brčko District have jurisdiction in the field of tourism, while the state harmonizes and coordinates existing laws. The legal regulation of tourism and hospitality in Bosnia and Herzegovina is solved by the entity Laws and the Laws of the Brčko District, which sum to 11 laws and 2 strategies.

\section{State level:}

1. The Law on Ministries and Other Bodies of Administration of Bosnia and Herzegovina (Official Gazette no. 5/03, 42/03, 26/04, 42/04, 45/06, 88/07, 35/09, 59/09 and 103/09). Deputy Minister of Foreign Trade and Economic Relations of Bosnia and Herzegovina (MoFTER) in the sphere of tourism is responsible for defining policies, basic principles, coordinating activities and harmonizing of entity authorities and institutions at the international level. 


\section{Entity level:}

Entity Federation of Bosnia and Herzegovina

2. The Strategy for Tourism Development in the FB\&H, covering the period 20082018 (not adopted)

3. Law on Tourism ("Official Gazette of FB\&H", No. 32/09)

4. Law on Hospitality Industry ("Official Gazette of FB\&H", No. 32/09)

5. Law on Tourism associations and Tourism promotion ("Official Gazette of FB\&H", No. 19/96 and 28/03)

Entity Republic of Srpska

6. Tourism Development Strategy of the Republic of Srpska for the period 2010-2020

7. Law on Tourism (Official Gazette RS, 101/07)

8. Law on Hospitality Industry ("Official Gazette of RS", No. 57/12)

9. Law on Tourist Accommodation Taxes ("Official Gazette of RS", No. 78/11)

10. Law on Public Ski Resorts ("Official Gazette of RS", 15/10)

11. Law on Spas (24/09)

\section{Brčko District:}

12. Law on Tourism ("BD Official Gazette", No. 3/06, 19/07)

13. Law on Hospitality Industry ("BD Official Gazette“, No. 31/05, 19/07)

Legal regulation is not harmonized, ant it is only applied at the territories of entities and Brčko District. The regulations on categorization and classification of hospitality facilities are also inconsistent, because they are solved at the entity and Brčko District levels. In the forthcoming period, it is necessary to harmonize the above-mentioned laws in accordance with EU Directives and Standards. This task is in charge of the Working Group for Tourism, which is established within MoFTER.

\section{TOURISM INDICATORS AND ITS CURRENT PERFORMANCE}

Bosnia and Herzegovina has been a top performer in postwar period in terms of tourism development, as tourist arrivals have grown by average of about $8 \%$ annually from 1999 to 2016. However, there is an exponential growth trend in the recent years averaging up to $13 \%$ in past decade, with the highest annual growth of $24 \%$ in 2015 . That was also the year in which the number of tourist visits to Bosnia and Herzegovina exceeded the figure of 1 million for the first time. The deregulation of the airline industry in Europe, the decline of pre-packaged tours that tend to stick to Western Europe and the greater recognition within the industry are important factors driving this growth. This increase is also partly due to the fact that Bosnia and Herzegovina has the advantage of being an inexpensive destination in Europe, even relative to southern states that boast relatively cheap accommodations and popular 
beaches. Air traffic, however, has proven an obstacle to attracting Western European tourists, the majority of international arrivals in the region. However, the explosion of budget airlines has helped overcome this barrier. In addition to that, in 2012, the Lonely Planet listed Sarajevo as a $2^{\text {nd }}$ best Eastern European getaway destination, and the year after that, the World Economic Forum reported in its Travel and Tourism Competitiveness Report that Bosnia and Herzegovina was the world's eighth friendliest nation towards tourists.

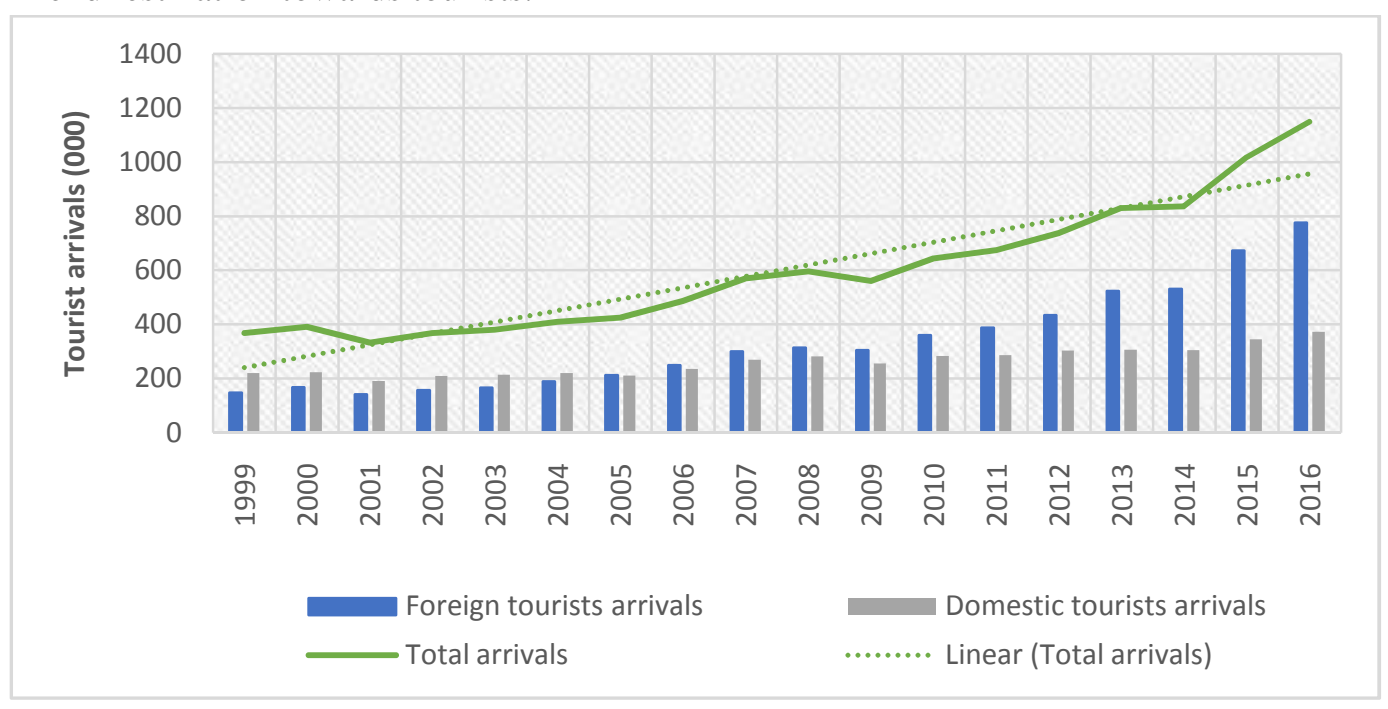

Fig. 2: Tourist arrivals in Bosnia and Herzegovina 1999-2016

The same year, The Huffington Post named Bosnia and Herzegovina the 9th greatest adventure in the World for 2013, adding that the country "boasts the cleanest water and air in Europe; the greatest untouched forests; and the most wildlife". To a small country that carries the image of a post-war destination, recognizing its numerous potencies in the aforementioned, and numerous similar articles and recommendations, have come as a very significant wind at the back and an incentive for its further development of tourism. According to an estimate of the World Tourism Organization, Bosnia and Herzegovina will have the third highest tourism growth rate in the world between 1995 and 2020 (UNWTO 2008). 


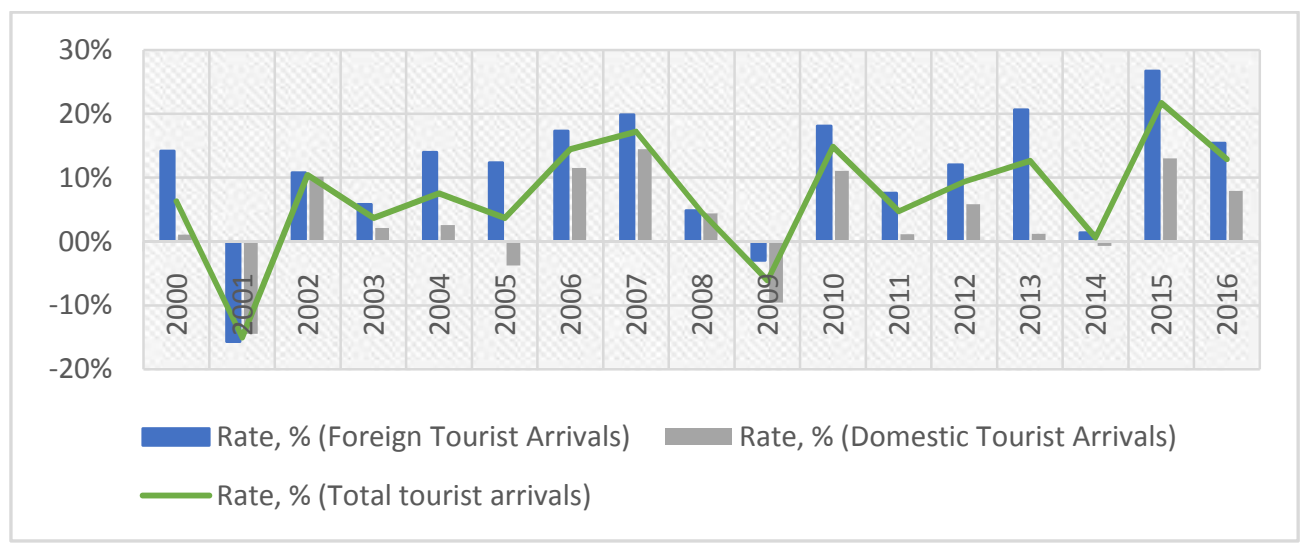

Fig. 3: Year-on-year rates of change in total tourist arrivals in Bosnia and Herzegovina (\%)

In conditions of global tourism business, tourism is constantly facing the crises that affect its development, and those of course have their impact in Bosnia and Herzegovina as well. At the beginning of the $21^{\text {st }}$ century, several significant crises have had a negative effect on the world's tourism industry, beginning with terrorist attacks on the United States, the epidemic, the World Economic Crisis, natural disasters, political crises, etc. Tourism resulted in a decline in tourism and revenue, with fewer or greater impacts on world tourism trends. The biggest, negative effects were achieved under the influence of the World Economic Crisis, when the indicators of tourism development were unfavorable throughout the world. At the height of the economic crisis, the rate of tourist arrivals in Bosnia and Herzegovina fell below zero and amounted to $-6.07 \%$ for 2009 . While many economic challenges like these continue to represent hurdles to sustained growth in Bosnia and Herzegovina, another, less predictable challenge also emerged during 2014, significantly hampering growth in the country and across the region as a whole: weather. Extreme weather events, including devastating floods in May, plagued much of the country throughout 2014 and negatively impacted nearly every economic sector in it - from agriculture, to energy, to tourism. Nevertheless, these major floods didn't result in another "below zero growth rate" episode for Bosnia and Herzegovina, but they did lead to stagnation of tourism sector, with growth rate of $0.66 \%$ in 2014 . However, as mentioned before, just year after that country has reached the growth rate of $24 \%$, with the uprising trend ever since. 


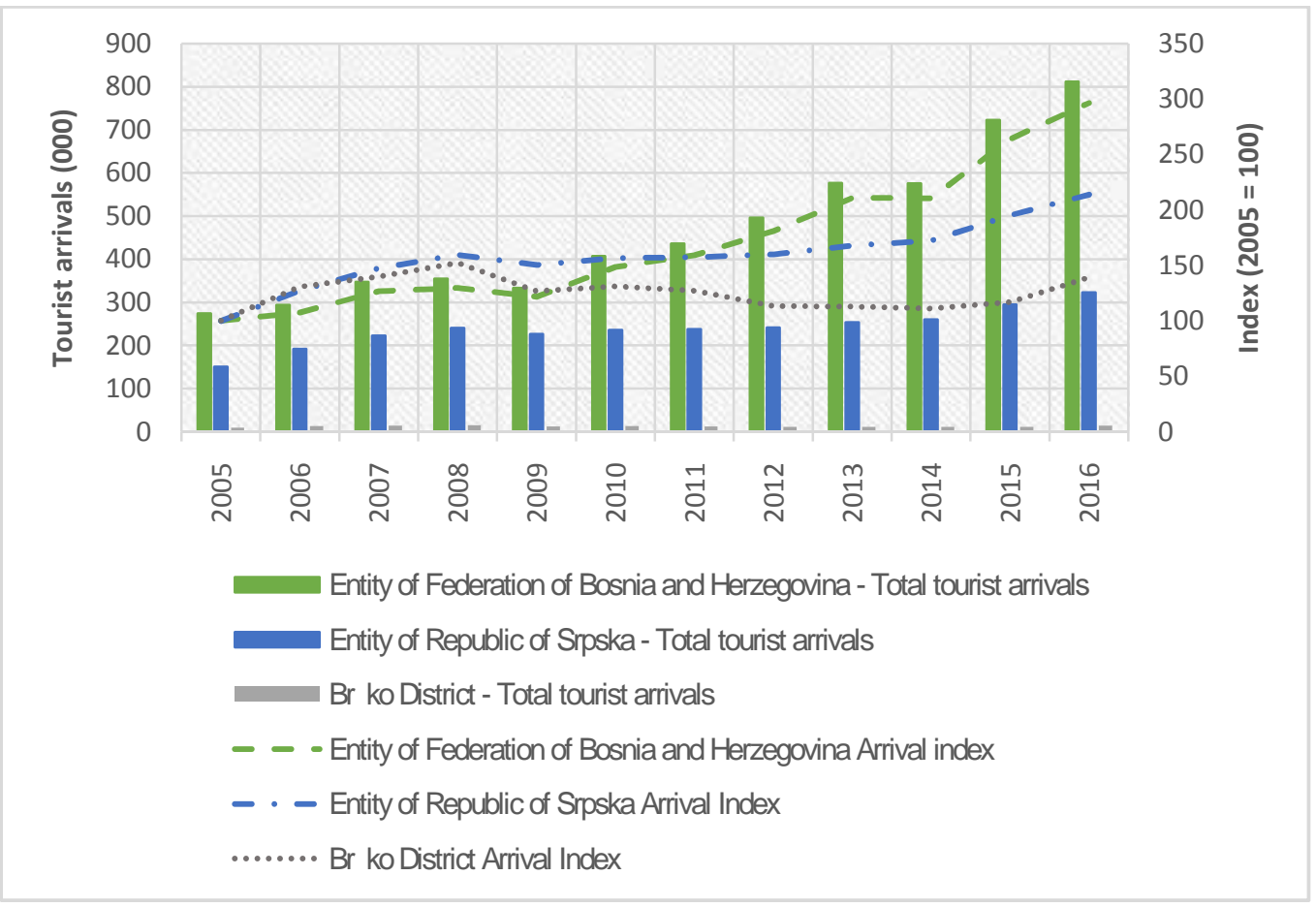

Fig. 4: Tourist arrivals at the entity and district level in Bosnia and Herzegovina

In the structure of overnight stays of foreign tourists in 2016, the highest number of nights were recorded by tourists from Croatia (11.9\%), Serbia (8.4\%), Turkey $(8.1 \%)$, Italy $(6.5 \%)$, Slovenia $(6.0 \%)$, Poland $(4.1 \%)$ and Germany $(4.0 \%)$, which is a total of 49 percent. Tourists from other countries made 51 percent of overnight stays. The countries of the region are characterized by a trend of a slight decrease in the number of tourist arrivals (an average of around $1 \%$ in the last two years), but at the same time an increase in the length of stay, which is on average about 2.1 nights. Tourists from Malta stay on average the longest (5.9 nights in 2016), then from Kuwait (3.7 nights), Ireland (3.5 nights), Qatar (3.3 nights), France and Iran (3.2 nights), Romania (3.1 nights) and the United Arab Emirates (3.0 nights in 2016).

Table 1: Tourism traffic and growth rate in Bosnia and Herzegovina 1999 - 2016.

\begin{tabular}{|c|c|c|c|c|c|c|c|c|c|c|c|c|c|}
\hline $\mathbb{d}^{\mathbb{8}}$ & $\frac{\frac{n}{0}}{\frac{0}{5}}$ & 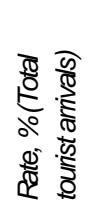 & 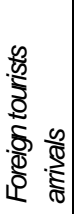 & 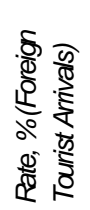 & 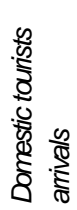 & 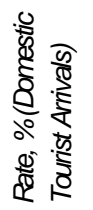 & $\begin{array}{l}\frac{0}{5} \\
\frac{5}{5} \\
\frac{8}{0} \\
\frac{\pi}{n}\end{array}$ & 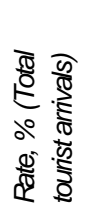 & 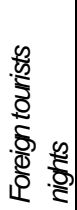 & 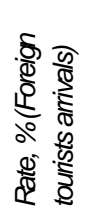 & 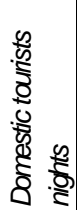 & 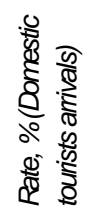 & $\begin{array}{l}\frac{\sqrt{4}}{4} \\
8 \\
8 \\
\frac{8}{4} \\
\frac{1}{4}\end{array}$ \\
\hline 1999 & 367 & & 147 & & 220 & & 948 & 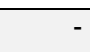 & 345 & & 602 & & 2.6 \\
\hline 2000 & 391 & $6.4 \%$ & 168 & $14.2 \%$ & 223 & $1.1 \%$ & 952 & $0.4 \%$ & 391 & $13.3 \%$ & 561 & $-6.9 \%$ & 2.4 \\
\hline 2001 & 332 & $-15.0 \%$ & 142 & $-15.7 \%$ & 190 & $-14.5 \%$ & 781 & $-18.0 \%$ & 331 & $-15.3 \%$ & 450 & $-19.8 \%$ & 2.4 \\
\hline 2002 & 367 & $10.4 \%$ & 157 & $10.8 \%$ & 210 & $10.2 \%$ & 890 & $14.0 \%$ & 394 & $18.8 \%$ & 497 & $10.4 \%$ & 2.4 \\
\hline
\end{tabular}




\begin{tabular}{|r|r|r|r|r|r|r|r|r|r|r|r|r|r|}
\hline 2003 & 380 & $3.7 \%$ & 166 & $5.9 \%$ & 214 & $2.1 \%$ & 901 & $1.2 \%$ & 407 & $3.4 \%$ & 494 & $-0.5 \%$ & 2.4 \\
\hline 2004 & 409 & $7.6 \%$ & 190 & $14.0 \%$ & 220 & $2.6 \%$ & 970 & $7.6 \%$ & 458 & $12.5 \%$ & 512 & $3.6 \%$ & 2.4 \\
\hline 2005 & 425 & $3.7 \%$ & 213 & $12.4 \%$ & 212 & $-3.7 \%$ & 994 & $2.5 \%$ & 474 & $3.4 \%$ & 520 & $1.7 \%$ & 2.3 \\
\hline 2006 & 486 & $14.5 \%$ & 250 & $17.4 \%$ & 236 & $11.6 \%$ & 1150 & $15.7 \%$ & 584 & $23.4 \%$ & 566 & $8.8 \%$ & 2.4 \\
\hline 2007 & 570 & $17.2 \%$ & 300 & $19.9 \%$ & 270 & $14.4 \%$ & 1313 & $14.1 \%$ & 683 & $17.0 \%$ & 630 & $11.2 \%$ & 2.3 \\
\hline 2008 & 596 & $4.6 \%$ & 314 & $4.8 \%$ & 282 & $4.4 \%$ & 1370 & $4.3 \%$ & 706 & $3.3 \%$ & 664 & $5.4 \%$ & 2.3 \\
\hline 2009 & 560 & $-6.1 \%$ & 305 & $-3.0 \%$ & 255 & $-9.5 \%$ & 1248 & $-8.9 \%$ & 662 & $-6.3 \%$ & 586 & $-11.6 \%$ & 2.2 \\
\hline 2010 & 643 & $14.9 \%$ & 360 & $18.1 \%$ & 283 & $11.0 \%$ & 1397 & $11.9 \%$ & 764 & $15.5 \%$ & 633 & $7.9 \%$ & 2.2 \\
\hline 2011 & 674 & $4.7 \%$ & 387 & $7.6 \%$ & 286 & $1.1 \%$ & 1485 & $6.3 \%$ & 827 & $8.2 \%$ & 658 & $3.9 \%$ & 2.2 \\
\hline 2012 & 737 & $9.4 \%$ & 434 & $12.0 \%$ & 303 & $5.9 \%$ & 1628 & $9.6 \%$ & 923 & $11.6 \%$ & 705 & $7.1 \%$ & 2.2 \\
\hline 2013 & 831 & $12.7 \%$ & 524 & $20.7 \%$ & 307 & $1.2 \%$ & 1765 & $8.4 \%$ & 1100 & $19.2 \%$ & 665 & $-5.7 \%$ & 2.1 \\
\hline 2014 & 836 & $0.7 \%$ & 531 & $1.4 \%$ & 305 & $-0.6 \%$ & 1694 & $-4.0 \%$ & 1079 & $-1.9 \%$ & 615 & $-7.5 \%$ & 2.0 \\
\hline 2015 & 1018 & $21.7 \%$ & 673 & $26.7 \%$ & 345 & $13.0 \%$ & 2038 & $20.3 \%$ & 1478 & $37.0 \%$ & 707 & $14.9 \%$ & 2.0 \\
\hline 2016 & 1149 & $12.9 \%$ & 77 & $15.4 \%$ & 372 & $8.0 \%$ & 2377 & $16.6 \%$ & 1641 & $11.0 \%$ & 735 & $4.0 \%$ & 2.1 \\
\hline
\end{tabular}

In the top 20 countries from which the most tourists come, some Asian countries are included such as Saudi Arabia, Kuwait, China and South Korea (BHAS, 2017). However, there is a strong trend in the increased number of arrivals and overnight stays from other Asian countries, which primarily relate to the countries of the Persian Gulf, such as Qatar, Bahrain and UAE. Most tourists actually come from Kuwait, then Qatar and the United Arab Emirates. In the structure of arrivals, married couples, as well as groups of mostly male friends and acquaintances, prevail. But when school breaks occur, many families come to a "collective holiday", so families who count 20 members often arrive. The phenomenon of a rapid increase in the number of tourists from Persian Gulf countries is evident through the fact that in 2013, only 3.004 tourists from Saudi Arabia visited Bosnia and Herzegovina, while the number of their visits increased up to 18.373 tourists in 2016, an increase of more than $600 \%$. The key question is why Bosnia and Herzegovina suddenly became interesting to tourists from the countries of the Persian Gulf, as tourist boards of Bosnia and Herzegovina do not lead any additional marketing campaign to attract tourists from these countries. It is certain that the opening of the air routes between Dubai-Sarajevo and Qatar- Sarajevo has contributed to the increase in the number of tourists from these countries. However, according to tourist guides, the greatest incentive for travel is actually created by social networks, and after that by recommendations of relatives, friends and acquaintances who have already visited Bosnia and Herzegovina. When studying trends in tourist arrivals, it is indispensable to analyze their geographical distribution. The methodology of our research was primarily based on the administrative division of the state, and therefore we analyzed the tourism traffic at the level of the two entities - the entity of the Federation of 
Bosnia and Herzegovina, which is divided into 10 Cantons, the entity of Republic of Srpska, which is dived in six Regions and the Brčko District. Even though the Republical Statistical Office of entity Republic of Srpska publishes statistical data on tourism on the municipal level, this paper considers only the figures on the regional level in the entity of Republic of Srpska, due to comparison ability with Cantons in entity of Federation of Bosnia and Herzegovina. When it comes to the entity level, we only considered the data from the year 2005 on, due to the lack of information on tourism trends for earlier period for the level of entity of Republic of Srpska. From Fig.4, one can notice that there is a trend of an increase in the number of tourists in both entities of Bosnia and Herzegovina, with a large entity disparity. Thus, the number of arrivals from the beginning to the end of the measurement period is significantly higher in entity of Federation of Bosnia and Herzegovina. The trend line points to a higher index of growth in the entity of Republic of Srpska by 2011. However, this can be attributed to the very small number of tourist arrivals in this entity in the base year. In any case, the number of tourists in both entities has a tendency to rise, especially in the recent years. District Brčko participates with roughly $1 \%$ in total state area, and its number of tourist arrivals does not have an important impact to total tourist arrivals. However, it had a downward and then stagnation trend in tourism in the period 2008-2015, which is primarily attributable to the fact that the former core of tourism development - the biggest Balkan open market, has moved to indoor premises, after which the number of visits to the area has dropped, and therefore the total number of tourist visits has decreased. But the number of tourist arrivals grew for $25 \%$ in 2016 in Brčko District, so it can be stated that this administrative unit also follows the linear trend of increase in tourism traffic along with the entities of Bosnia and Herzegovina. Canton Sarajevo is actually the bearer of the tourist offer in Bosnia and Herzegovina, with more than $35.5 \%$ share in total arrivals in 2016 and more than $50 \%$ of the arrivals at the level of entity of Federation of Bosnia and Herzegovina, followed by the Herzegovina-Neretva Canton with around $20.4 \%$ of total arrivals at the state level in the same year. Banja Luka Region shares about $12 \%$ of total tourist arrivals in 2016 , which is roughly $40 \%$ of total arrivals in the entity of Republic of Srpska. Central Bosnia, Tuzla and Una-Sana Cantons in entity of Federation of Bosnia and Herzegovina as well as Regions Doboj, East Sarajevo, Trebinje and Zvornik - Bijeljina in the entity Republic of Srpska each share about $4 \%$ of total arrivals, while remaining five Cantons of entity of Federation of Bosnia and Herzegovina (Posavina, Bosnian Podrinje, West Herzegovina, Canton 10 and Zenica-Doboj Canton) along with Region Foča in the entity of Republic of Srpska together share about $5 \%$ of total number of tourist arrivals in Bosnia and Herzegovina in the measurement year. These data indicate the presence of significant regional disparity, as there are three major cores of tourism development - Sarajevo, Mostar and Banja Luka, while some other parts of Bosnia and Herzegovina have an exceptional natural, cultural and historical potential but their problem with an 
inadequate and insufficient tourist infra and supra-structure and lack of an adequate tourism planning approach prevents their faster touristic development.

\section{ECONOMIC IMPACT OF THE TOURISM SECTOR IN BOSNIA AND HERZEGOVINA}

Despite the fact that Bosnia and Herzegovina is getting more tourists each year and that it has an obvious potential for furtherer development of this branch of economy, the fact is that with the increase in the number of tourist visits, gray economy in the field of tourism is also increasing. Non-registration of accommodation capacities and guests and non-payment of residence tax are just some of the ways in which extra profit is

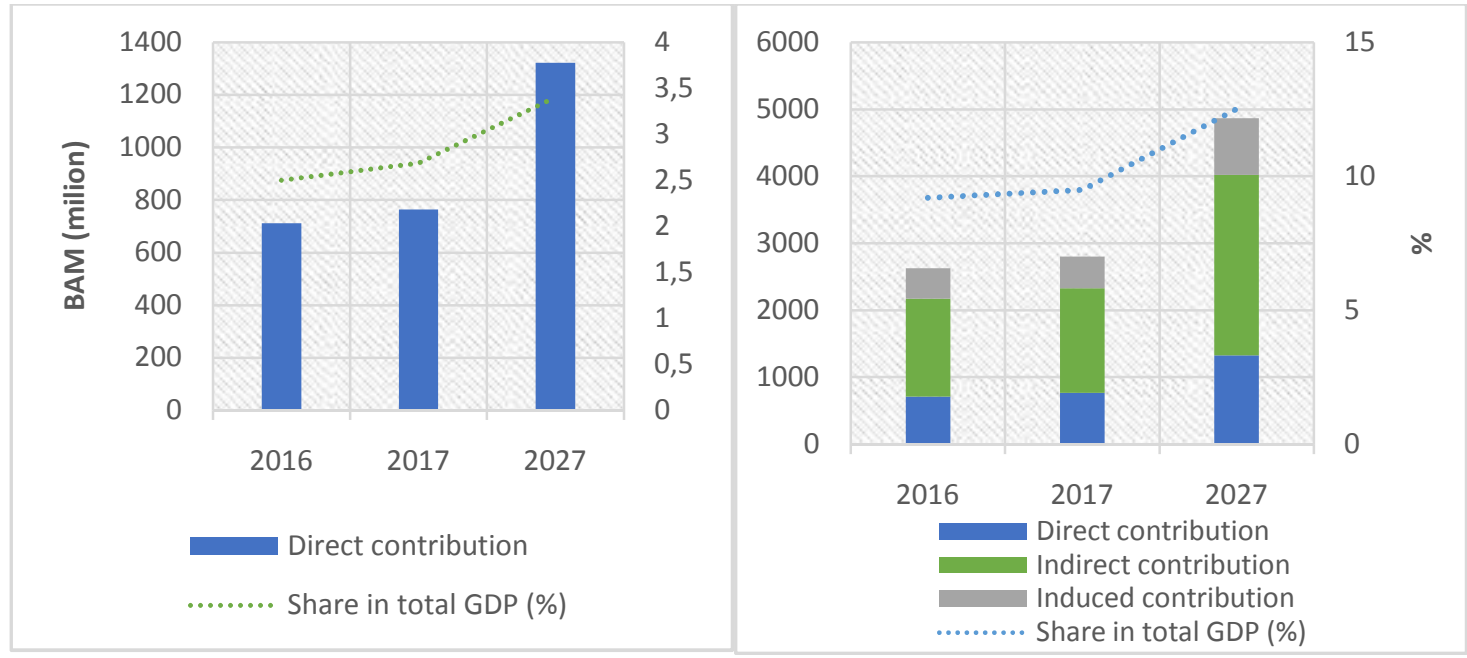

Fig. 5: Direct contribution of tourism sector to Bosnia and Herzegovina's GDP

Fig. 6: Total contribution of tourism sector to Bosnia and Herzegovina's GDP being sought. The budget and tourist workers who work according to the Law are at a loss, and finally the tourist offer as well. According to the report of the World Tourism Organization (UNWTO, 2016), Bosnia and Herzegovina is on the list of countries that recorded the most significant growth in tourist visits, but it is assumed that the real number of tourist arrivals is far greater than that indicated by official statistics. Tourism Associations all over the country are facing a major problem with the mass phenomenon that the large number of accommodation facilities are not reporting tourist overnight stays to the Tourist Board. There is no accurate data when it comes to income from tourism, but it is estimated that the so-called gray zone in Bosnian-Herzegovinian tourism takes up to 500 milion euros annually. In order to introduce more order in $\mathrm{BH}$. Tourism, the Government of the Federation has established a Draft Law on Tourism, which, among other things, envisages the introduction of the so-called Tourism Register, in which categorized and unclassified catering facilities will be recorded. 
Until gray economy in the field of tourism is regulated, everyone is at a loss, due to the fact that quality standards of tourist services are decreased. According to the World Travel and Tourism Council (WTTC) report for 2016, the direct contribution of travel and tourism to Bosnia and Herzegovina's GDP was 711 milion BAM, which is $2.5 \%$ of total GDP in 2016 and is forecast to increase by $5.6 \%$ annually to 1,3 bilion BAM in 2027 (Fig. 5). On the other hand, the total contribution of travel and tourism (which has a wider impacts, i.e. the indirect and induced impacts to economy) to GDP was BAM 2.6 bilion or $9.2 \%$ of GDP in 2016 , and is forecast to by $5.7 \%$ to BAM 4.9 bilion (12.5\% of GDP) in 2027 (Fig. 6). In 2016, travel and tourism directly supported 22.000 jobs (3.0\% of total employment). Direct contribution to employment is expected to increase by $2.6 \%$ to 30.000 jobs (4.4\% of total employment) in 2027 (Fig. 7) while the total contribution of travel and tourism to employment, including jobs indirectly supported by the industry is expected to take up to $15 \%$ of total jobs in the same year
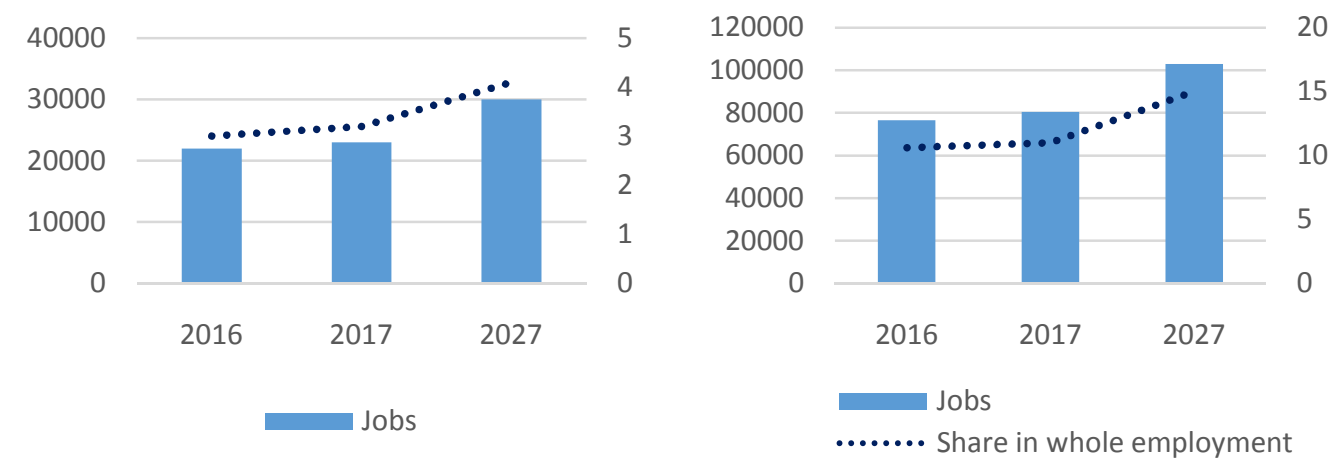

Fig. 7: Direct contribution of tourism sector to employment in Bosnia and Herzegovina

Fig. 8: Total contribution of tourism sector to employment in Bosnia and Herzegovina

\section{DISCUSSION AND CONCLUSION}

Future tourism development perspectives in Bosnia and Herzegovina are positive, as indicated by $10+$ year trends as well as the strategic assessments at the state and entity levels. There is a linear trend of increasing the number of tourist arrivals and overnight stays at all levels of strategic organizational units in Bosnia and Herzegovina - the entity of the Federation of Bosnia and Herzegovina, the entity of the Republic of Srpska and even Brčko District, where the development of tourism has stagnated for the past few years. The above stated claim is also supported by the fact that tourism is set on the $2^{\text {nd }}$ place in strategic macroeconomic orientation of Bosnia and Herzegovina and it is also recognized as one of the key branches of economic development in spatial plans of 
the highest order. The aforementioned positive trends are also in line with the World Travel and Tourism Council forecasts, according to which the direct contribution of tourism to Bosnia and Herzegovina's GDP will increase by $200 \%$ over the next decade, the total (direct, indirect and induced) contribution of tourism to Bosnia and Herzegovina's GDP will increase by $88 \%$ in the same period, providing the $15 \%$ of total jobs in 2027. In addition, professional staff in tourism is increasingly more educated, as a result of the fact that at the high school and programs of higher education institutions create curricula that are consistent with market trends and needs and tourism infrastructure and supra-structure are constantly improving. However, the fact is that the gray economy in the country cannot be ignored. Despite the shifts made by the Federal Government by drafting the new Law on Tourism, it is necessary to define the priorities in the development of this area at the state level. This primarily relates to the adoption of the Law on Tourism at the State level, and the harmonization of entity laws with it. An establishment of the Agency for Tourism or a special administrative organization at the State level is also an imperative and it should be followed by an institutional strengthening of the tourism sector in the organizational structure of ministries and tourist associations - organizations. In order to furtherly develop this economy sector it is also necessary to establish a development strategy of tourism in Bosnia and Herzegovina and to establish a continuity in creating an annual marketing and tourism promotion plans. Bosnia and Herzegovina can improve its position in the regional market by building higher quality tourism with innovative concepts. Standard development models should be avoided as the focus of tourism development should be tourism of special interests, such as adventure tourism, ethno villages, wine tourism, cultural - historical tours etc. This is due to the fact that, in order to maintain a positive trend in tourism traffic, Bosnia and Herzegovina must compete with a wide choice of tourist destinations, which have a significant budget to attract tourists. For Bosnia and Herzegovina, in order to create its competitive advantage in relation to those destinations with similar tourism resources and natural beauties, it must first be clearly positioned. Tourism promotion should be based on research of the visitors' needs, and reflecting the products and experiences that have been developed on the basis of market trends. Destination management should be perennial, with the foresight of trends, themes and emerging markets. It should also be well integrated, from the first point of contact to the visit and after-sales service after-sales effects and customer/visitor satisfaction, in order to provide the necessary data for adapting and changing tourism development strategies as needed. Finally, an establishment of an operational team for the development, implementation and evaluation of the effects of the implementation of measures is necessary in order to continue the positive trends in tourism in Bosnia and Herzegovina. 


\section{REFERENCE LIST}

1. Babić-Hodović, et al. "Assessing sustainability and eco-tourism consciousnesses amongst students and tourism service providers." Acta geographica Bosniae et Herzegovinae, 3 (5) (2016): 31-50.

2. Bansal, H., Eiselt, H. „Exploratory research of tourist motivations and planning“. Tourism Management, 25 (3), (2004): 387-396.

3. BHAS: Saopćenje: Statistika turizma: Kumulativni podaci, januar - decembar 2016., Sarajevo: Agencija za statistiku Bosne i Hercegovine (2017)

4. Deng, J. et al. „Evaluating natural attractions for tourism“. Annals of Tourism Research, 29 (2) (2002): 422-438.

5. Dredge, D. „Policy networks and the local organization of tourism. Tourism Management, 27 (2), (2006): 269- 280.

6. Dredge, D., Moore, S. „A Methodology for the Integration of Tourism in Town Planning “. The Journal of Tourism Studies, 3(1), (1992): 8-21.

7. Drešković, N. et al. "Possibilities of GIS application in the organization and presentation of tourism potentials-Case study of Sarajevo." International Scientific Conference Geobalcanica 2015. (2015): 119-126.

8. Filieri, R., \& McLeay, F. „E-WOM and accommodation an analysis of the factors that influence travelers' adoption of information from online reviews “. Journal of Travel Research, 53 (1) (2014): 44-57.

9. Hall, C.M. Tourism Planning: Policies, Processes and Relationships (2nd Ed.). Essex: Pearson Education (2008): 163-191.

10. Hall, C. M., Page, S.J. The geography of tourism and recreation: Environment, place and space. London: Routledge (2014): 1-33.

11. Khadaroo, J., Seetanah, B. „Transport infrastructure and tourism development“. Annals of Tourism Research, 34 (4), (2007): 1021-1032.

12. Korjenić, A. Spatial planning in Bosnia and Herzegovina - Legislative framework, Acta geographica Bosniae et Herzegovinae 3 (2016): 53-62.

13. Lau, G., McKercher B. "Understanding Tourist Movement Patterns in a Destination: A GIS Approach." Tourism and Hospitality Research, Vol 7, Issue 1, (2007): $39-49$.

14. Lew, A., McKercher, B. „Modeling Tourist Movements: A Local Destination Analysis“. Annals of Tourism Research, 33 (3), (2006): 403-423.

15. Lue, C.-C. et al. „Evidence of Cumulative Attraction in Multidestination Recreational Trip Decisions. “ Journal of Travel Research, 34, (1996): 41-49.

16. Masiero, L., Zoltan, J. „Tourists intra-destination visits and transport mode: a bivariate probit model“. Annals of Tourism Research, 43, (2013): 529-546.

17. Mason, P. Tourism Impacts, Planning and Management, Oxford: ButterworthHeinemann (2003): 53-68. 
18. Mckercher, B., Lau, G. „Movement Patterns of Tourists within a Destination.“ Tourism Geographies: An International Journal of Tourism Space, Place and Environment, 10 (3), (2008): 355-374.

19. Mill, R.C., Morrision A.M. The Tourism System, Dubuque: Kendal/Hunt (2002)

20. Milne S., Ateljevic I. „Tourism, economic development and the global-local nexus: Theory embracing complexity“, Tourism Geographies, 3:4, (2001): 369393.

21. Mirić, R. et al. "Concepts of Tourism Regionalization and Analysis of Contemporary Trends of Tourist Movement in Bosnia and Herzegovina." Proceedings Book 2nd International Tourism and Hospitality Management Conference, Faculty of Science, University of Sarajevo, (2017): 293-303.

22. Mowforth, M., Munt, I. Tourism and Sustainability: New Tourism in the Third World. London: Routledge. (1998): 94-111.

23. Schubert, S. et al. "The impacts of international tourism demand on economic growth of small economies dependent on tourism”. Tourism Management, 32 (2011): 377-385.

24. Sivac, A. et al. „The Correlation between Spatial Planning and Sustainable Tourism Development - Case Study of Bosnia and Herzegovina“. Proceedings Book 2nd International Tourism and Hospitality Management Conference, Faculty of Science, University of Sarajevo (2017): 262-279.

25. United Nation World Tourism Organization: Tourism Highlights - 2008 Edition, Madrid: UNWTO (2008)

26. World Tourism Organization: Tourism Highlights - 2016 Edition, Madrid: UNWTO (2016)

27. World Travel and Tourism Council: Travel \& Tourism Economic Impact 2016Bosnia and Herzegovina. London: WTTC (2017)

28. Zoltan, J., McKercher, B. "Analysing intra-destination movements and activity participation of tourists through destination card consumption"s. Tourism Geographies: An International Journal of Tourism Space, Place and Environment, 17 (1), (2015): 19-35. 